\title{
Collective action and ecological sensibility for sustainable mangrove governance in Indonesia: challenges and opportunities
}

\author{
Astrid Meilasari-Sugiana ${ }^{1}$ \\ Universitas Bakrie, Indonesia
}

\section{Introduction}

Indonesia's population reached 210 million in 2000, with a growth rate of $1.8 \%$ per annum. Approximately 41 million people, or $22 \%$ of the population, live in or near coastal areas (BPS 2000: 5). Half of these are dependent on local coastal resources for their livelihood. Marine related activities account for 20\% of total Gross Domestic Product (GDP), and 19\% of non-oil and gas GDP. Moreover, the coastal areas provide employment and income for about 16 million people or $24 \%$ of the national labor force (Bappeda 1998: 11). Coastal mangroves (Rhizophoraceae and other species) are overexploited for their wood, despite their importance for the sustainability of marine and coastal fisheries. There is also potential for major expansion in aquaculture production and rice farming in mangrove areas. This expansion, if not carefully planned and controlled, will destroy valuable natural resources including coastal mangroves themselves (Andrianto 2006; Barber 2002).

During the era of President Suharto (1967 - 1998), natural resource governance in Indonesia was marked by exploitation. Suharto's regime emphasized development that was primarily based on centralized and top down decision-making to ensure political stability and economic growth (Resosudarmo 2006). Despite efforts to decentralize toward the end of the regime, its initiatives were marked by asymmetrical access to strategic and structural power. This undermined local democracy, curtailed community participation and led to uncontrolled exploitation of the country's natural resources (Barr et al. 2006; Siswanto 2005). To promote social inclusion and sustainable natural resource governance, during the post-Suharto era (from 1998) the Government of Indonesia (GOI) has adopted principles of community based natural resource governance that focus more on resource allocation decision making at the village, district and regency levels. The regency government, along with the district management and local user communities, were given the right to manage Indonesia's natural resources (Satria 2002).

This article discusses a later phase of the GOI's community based natural resource governance program in the Regency of Sinjai, South Sulawesi Province (Figure 1). The program is the governmentendorsed mangrove conservation scheme in the village of Tongke Tongke, initiated by local villagers (YTMI 2003; Figure 2). The case has received some popular attention due to the success of community efforts to replant mangroves in a coastal area threatened by marine erosion, and the award of a major environmental prize for their efforts in the 1990s (Amri 2005; Nightingale nd; Hamid 2002). ${ }^{2}$

Many of Tongke Tongke's programs for promoting sustainable coastal resource governance have been under the jurisdiction and authority of diverse regency government departments, as opposed to being centrally administered (Prioharyono 2002). These programs contributed to the work of multiple user communities, and have created new spaces and opportunities for reinforcing a discourse of mangrove conservation. The purpose of this article is to examine the interaction between on-ground practices and government policies and programs for sustainable mangrove governance, and to understand the complex and dynamic power relations that influence collective action for resource sustainability and conservation. I examine the social institutions and social relationships that need to emerge and endure to support the social cohesion and conservation of the mangroves, also providing lessons from a failed effort to conserve a population of bats that previously occupied the mangroves around Tongke Tongke.

\footnotetext{
1 Dr. Astrid Meilasari-Sugiana, Lecturer, Department of Political Science, Universitas Bakrie, Jl. H.R.Rasuna Said Kav. C-22, Jakarta 12920, Indonesia. Email: meilasari "at" bakrie.ac.id. Thank you to the two reviewers and the journal Editor for providing useful comments and suggestions. The study was kindly funded by an AusAid - ADS PhD award.

2 The mangrove species present were primarily Nypa fructans, Avicennia Spp, and Bruguiera Spp., but planting was of Rhizophora mucronata (Nightingale nd).
} 


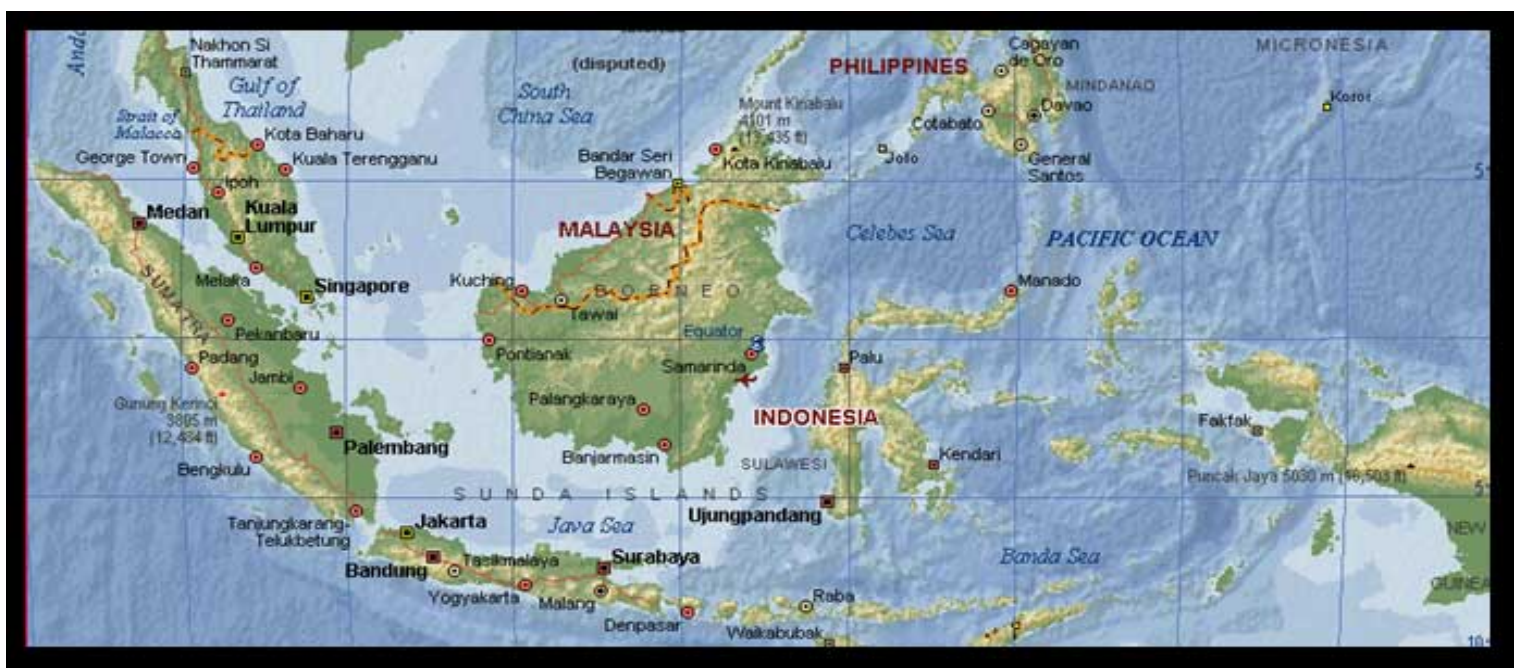

Figure 1: Map of the Indonesian Archipelago

\section{Research methods}

This study used ethnographic and qualitative research methods. An ethnographic approach was able to disclose the social and political constructions of the ecological landscape and the natural resources at the case study site. The study examined the "rules" for constructing social reality, and how these rules are applied, maintained and transformed in the face of power relations. Detailed documentation of the events and discourses that emerged, as well as my reflections on these, were recorded, compared and analyzed to disclose the habits, attitudes and beliefs of the various research subjects (Baba 1994; Geertz 1973).

A pilot study in South Sulawesi was conducted from August 2004 until October 2004. Data collection was conducted from March 2005 until August 2005. I returned to Sinjai in 2008 and 2009, each time for two months. Interviews with government officials from South Sulawesi were conducted in the capital Makassar and in Sinjai's capital city, Sinjai City. Methods included participant observation and in-depth interviews (Pels 2003), and the compilation of secondary data in relation to government policies, programs and projects in South Sulawesi. Detailed accounts were needed of the social and political phenomena associated with natural resource governance (Wenger 1998). I used un-structured but thematically focused interviews to understand how social phenomena and their meaning are constructed and perceived (Turnbull 2001; Yin 1984). I also wrote and compiled daily accounts of observations and my experiences in diary format.

Community members were interviewed in the village of Tongke Tongke. Interviews with noncommunity leaders were conducted at home and/or outdoor in the presence of one to three other people who were relatives and neighbors of the research informants. Community leaders preferred to be interviewed on their own in their private homes. After regular visits and routine communication exchanges, research informants began to open up and state their perspectives on local participation for the collective management of natural resources, especially the mangroves. The data was then transcribed and triangulated through further interviews, participant observation and a closer scrutiny of the physical landscape. In order to promote trust, I talked with local people on a daily basis and assured them of the confidentiality of the raw data (Neuwman 2003).

Secondary data was obtained from government departments, donor agencies, NGOs, government consultants and academics directly through private meetings, and indirectly through internet publications and university and private libraries. There was a need to understand the perspectives and interests of the officers involved in the planning and implementation of natural resource governance policies, programs and projects (Cornwall 1994). Textual analysis was used to analyze secondary data. ${ }^{3}$

\footnotetext{
${ }^{3}$ The N-Vivo program was used for data storage and organization purposes. Texts obtained from the interviews and daily notes were coded (Bryman 2001; Crotty 1998). Next, I compared data and contexts across the interviews to accentuate and explain the specific and unique (Bryman 2001; Crotty 1998). The illustrative method was then applied to determine the core categories and their sub-dimensions, and to integrate ideas into hypotheses between core categories. These included instrumental views of nature's value. I looked for a discrepancy between policy objectives and the events surrounding the implementation of those policies.
} 
Subsequently I looked at the social and political alliances of resource users, the configurations of power within the policy and village community, the rules underlying the social and political engagements among natural resource users. These concrete details were then used to generate a comprehensive analysis of collective natural resource governance. They were also used to acquire new insights into facilitating social responsiveness, active participation and inclusiveness in the sustainable governance of Indonesia's natural resources. Lastly, I attempted to discern thoughts and/or behavior patterns by comparing, contrasting and sorting the various categories which emerged from the data (Bryman 2001; Crotty 1998).

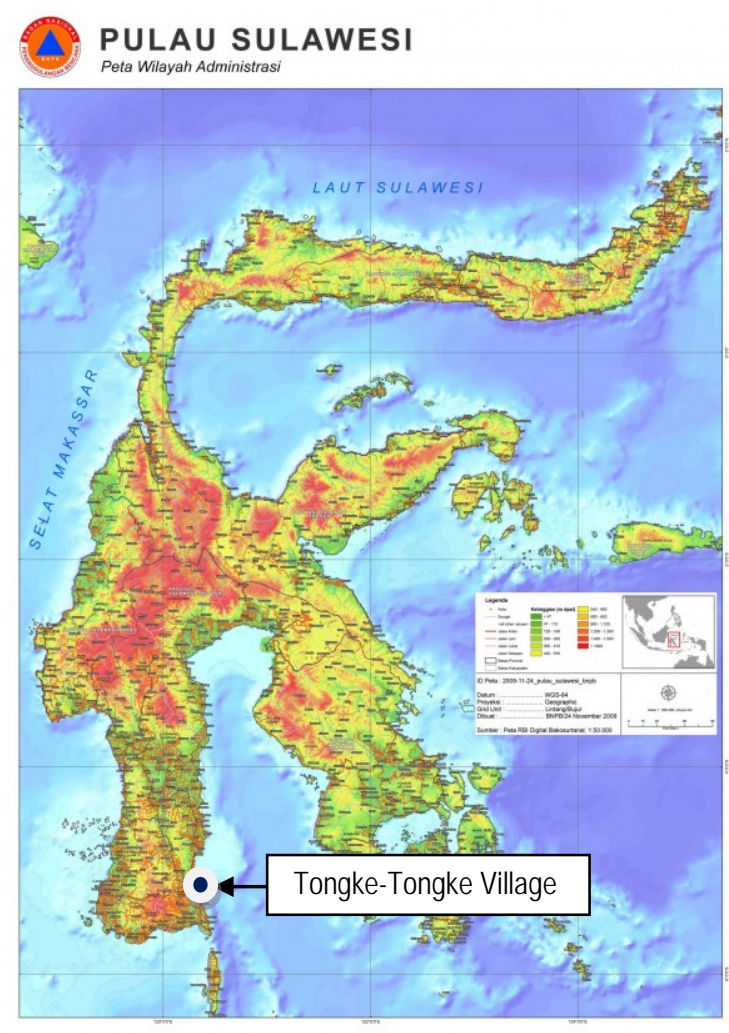

Figure 2: The island of Sulawesi and the village of Tongke-Tongke

The informants invited to participate in the research were those involved in the development and implementation of policies, programs and projects in the Tongke Tongke. In addition, community members and officials targeted by government schemes were also invited to participate. The categories of research informants who were invited to participate in South Sulawesi, along with their numbers and reasons for each category, are depicted in Figure 3. The results of the study are now presented in three major sections.

\section{Village level mangrove organization and devolution}

During the late 1990s indigenous uprisings, resistance from the provincial and regency government, and the demand for regional independence by separatist movements all contributed to Suharto's downfall (Thorburn 2001). The challenges of natural resource governance during the post-Suharto era required the government to address all of these issues (Bebbington et al. 2006). This led to a new era of rapid and wide ranging changes to Indonesia's social and political configurations.

A major achievement during the post Suharto era was the promulgation of Forestry Act No. 41/1999 which recognizes the contribution of indigenous groups and their territories (Siswanto 2005). The Act was further supplemented with Ministerial Decree No. 5/1999 which stipulates the procedure for resolving conflicts over land use and indigenous rights (Benda-Beckmann 2001). In 2002, Regulation No. 34/2002 on forest management was adopted by the national government as a supplement to the Forestry Act, to address indigenous rights and social justice (Savitri 2006). Furthermore, the implementation of Law No. 34/2002 stipulates that "all development activities undertaken by government agencies...must promote the spirit of good governance, meaning that local government should take the authority and responsibility for conducting development activities in a transparent and accountable manner" (Siswanto 2005: 144). The adoption of these laws reinforced the government's commitment to collective management at the regency and community level. Consequently, the regency government, acting as an autonomous entity, had the authority to work with community members for sustainable governance of Indonesia's natural resources (Munasinghe 1995). 
Coupled with international pressure to acknowledge indigenous rights and to devolve natural resource governance to community user groups, the GOI adopted community based natural resource governance in which local user communities are given the rights to decide and enforce natural resource allocation at the village level - provided that it is in line with regency initiatives and national directives (Moeliono 2006).

\begin{tabular}{|c|c|c|c|}
\hline $\begin{array}{c}\text { Research } \\
\text { informants }\end{array}$ & Reasons & $\begin{array}{c}\text { Research } \\
\text { informants }\end{array}$ & Reasons \\
\hline $\begin{array}{l}\text { NGO representatives } \\
\text { ( } 2 \text { informants) }\end{array}$ & $\begin{array}{l}\text { Aid government officials in } \\
\text { facilitating conflict resolution } \\
\text { among the mangrove cultivators. }\end{array}$ & $\begin{array}{l}\text { Village officials } \\
\text { (3 informants) }\end{array}$ & $\begin{array}{l}\text { The forefront personnel in } \\
\text { promoting and implementing } \\
\text { new initiatives in villages. }\end{array}$ \\
\hline $\begin{array}{l}\text { Project consultants, } \\
\text { researchers and } \\
\text { academicians } \\
\text { (2 informants) }\end{array}$ & $\begin{array}{l}\text { Aid the regency planning board in } \\
\text { planning its annual coastal zone } \\
\text { management programs and projects. }\end{array}$ & $\begin{array}{l}\text { Community leaders } \\
\text { from mangrove and } \\
\text { religious groups } \\
\text { (5 informants) }\end{array}$ & $\begin{array}{l}\text { The status quo in } \\
\text { TongkeTongke who are } \\
\text { respected and aspired to by } \\
\text { villagers. }\end{array}$ \\
\hline $\begin{array}{l}\text { Members of the } \\
\text { house of } \\
\text { representatives } \\
\text { ( } 2 \text { informants) }\end{array}$ & $\begin{array}{l}\text { Approves the selection and funding } \\
\text { of policies, programs and projects. }\end{array}$ & $\begin{array}{l}\text { The elderlies who } \\
\text { left the mangrove } \\
\text { organization } \\
\text { (4 informants) }\end{array}$ & $\begin{array}{l}\text { The status quo which are } \\
\text { respected and aspired to by } \\
\text { villagers. }\end{array}$ \\
\hline $\begin{array}{l}\text { District head } \\
\text { (1 informant) }\end{array}$ & $\begin{array}{l}\text { The forefront personnel responsible } \\
\text { for managing issues and projects } \\
\text { within the villages. }\end{array}$ & $\begin{array}{l}\text { Bat poachers } \\
\text { ( } 2 \text { informants) }\end{array}$ & $\begin{array}{l}\text { Contended with mangrove } \\
\text { cultivators and plot owners for } \\
\text { poaching bats in forest. }\end{array}$ \\
\hline $\begin{array}{l}\text { The provincial } \\
\text { planning board } \\
\text { ( } 2 \text { informants) }\end{array}$ & $\begin{array}{l}\text { Coordinates coastal zone } \\
\text { development policies across the } \\
\text { regencies. }\end{array}$ & $\begin{array}{l}\text { Aquaculture } \\
\text { farmers who are } \\
\text { mangrove owners } \\
\text { (5 informants) }\end{array}$ & $\begin{array}{l}\text { Targeted by the mangrove and } \\
\text { fishery policies and programs }\end{array}$ \\
\hline $\begin{array}{l}\text { The provincial } \\
\text { forestry department } \\
\text { ( } 2 \text { informants) }\end{array}$ & $\begin{array}{l}\text { Collaborates with the regency's } \\
\text { forestry department to promote the } \\
\text { village's mangroves. }\end{array}$ & $\begin{array}{l}\text { Landowner, fish } \\
\text { merchant and } \\
\text { capital lender } \\
\text { (1 informant) }\end{array}$ & $\begin{array}{l}\text { Middle class at the forefront to } \\
\text { induce initiatives and change. }\end{array}$ \\
\hline $\begin{array}{l}\text { The regency planning } \\
\text { board } \\
\text { (1 informant) }\end{array}$ & $\begin{array}{l}\text { Plans and approves the selection } \\
\text { and funding of policies, programs } \\
\text { and projects forwarded by various } \\
\text { regency government sectors. }\end{array}$ & $\begin{array}{l}\text { Mangrove } \\
\text { cultivators } \\
\text { (15 informants) }\end{array}$ & $\begin{array}{l}\text { Contentions among cultivators } \\
\text { led to insurgence, changing } \\
\text { power relations and } \\
\text { participation in village. }\end{array}$ \\
\hline $\begin{array}{l}\text { The regency marine } \\
\text { and fishery resource } \\
\text { department } \\
\text { ( } 2 \text { informants) }\end{array}$ & $\begin{array}{l}\text { Plans, implements and funds } \\
\text { fishery and aquaculture } \\
\text { development projects and fishery } \\
\text { management projects. }\end{array}$ & $\begin{array}{l}\text { Migrant laboring } \\
\text { fishermen and } \\
\text { migrant farm } \\
\text { laborers. } \\
\text { (5 informants) }\end{array}$ & $\begin{array}{l}\text { Targeted by the fishery } \\
\text { policies, programs and projects } \\
\text { for improved sustainability. }\end{array}$ \\
\hline $\begin{array}{l}\text { The regency forestry } \\
\text { department } \\
\text { ( } 2 \text { informants) }\end{array}$ & $\begin{array}{l}\text { Plans, implements and monitors } \\
\text { policies, programs and projects } \\
\text { related to forest management. }\end{array}$ & $\begin{array}{l}\text { Non migrant in-land } \\
\text { fishermen } \\
\text { (5 informants) }\end{array}$ & $\begin{array}{l}\text { Decision makers and owners of } \\
\text { boats targeted by projects. }\end{array}$ \\
\hline $\begin{array}{l}\text { The regency spatial } \\
\text { planning board } \\
\text { (1 informant) }\end{array}$ & $\begin{array}{l}\text { Collaborates with donor agencies } \\
\text { and government departments for } \\
\text { developing infrastructure and } \\
\text { managing land use within villages. }\end{array}$ & $\begin{array}{l}\text { Housewives and } \\
\text { women fish traders } \\
\text { ( } 5 \text { informants) }\end{array}$ & $\begin{array}{l}\text { Play key roles in household } \\
\text { decision making \& targeted by } \\
\text { development projects. }\end{array}$ \\
\hline
\end{tabular}

Figure 3 - Research informants in South Sulawesi

Community members in Tongke Tongke cultivated and nurtured the village mangroves to protect against wave encroachment in the early 1980s. The village has a long history of fishing, and interest in mangrove cultivation stemmed from the need to create new land, and to protect the village against tidal waves. With the passing of time, community members' attachment to the mangroves grew, and they were perceived as a source of identity, pride, social status and material wealth. In the late-1980s the cultivators formed a mangrove organization called ACI (i.e. Aku Cinta Indonesia or I Love Indonesia). The ACI organization was formed to acknowledge the cultivators' effort and protect the community's mangroves. In 1995 Tongke Tongke received the major Kalpataru Environmental Award from Indonesia's President for their work. Because the mangrove issue could potentially attract national support, the regency and provincial governments converted the mangroves into a state owned park with community based management rights, endorsed the ACI mangrove organization, and appointed one of the members as ACI's head in 1999. Although the area is presently 'disputed' (see Amri 2008:14), today there are 550 hectares of mangroves and 
the ACI mangrove organization has a head, deputy head and treasurer. Rules, although informal, govern the use, allocation and governance of the mangroves. They stipulate that the extraction of plants and animals requires consent from the mangrove owners and the head of ACI. Moreover, ACI's senior members claimed that these unwritten rules also encompass those who are allowed to enter the mangrove forest. There are rules for extraction of marine biota, logging of timber, and sanctions for trespassers and violators. The owners allow villagers to extract dead wood and hermit crabs for their consumption, and for sale in the local market. However, outsiders are not permitted to take anything or even to enter without consent: "we have to protect the trees and the land from foreigners who want to enter for research, recreation and business" stated Mr. ABDRF. The sanction for cutting live mangroves include having to plant and nurture the same number of trees until reaching maturity. Nevertheless, these rules are neither formulated through joint decision making nor are they formalized in meetings and village regulations.

The un-written rules for privatizing Tongke Tongke's mangroves are perceived necessary for protecting local private interests, safeguarding the resource from external parties, and reasserting familial ties to the land and to coastal waters. According to ACIs vice head, Mr. ZNDN, immigrants from the outer islands of Indonesia began settling the village when community members started cultivating the mangroves; hence, they saw the need to privatize the mangroves to assert property rights and to maintain familial ties to the land and coastal waters. Despite being privatized, the discourse underlying the governance of Tongke Tongke's mangroves suggests the need for more collective management and resource conservation. In the case of Tongke Tongke's mangroves, the provincial and regency governments converted the mangroves into a park and thus considered the mangroves state owned property (Amri 2005). Nonetheless, the ACI members who planted and nurtured the mangroves suggested that the government was encroaching on their mangroves, which, based on indigenous laws have been plotted and privatized long before the arrival of the government. The ACI members considered the mangroves private property that is to be communally managed and conserved. Hence, public tenure is attached to the mangroves, but private ownership and communal governance are also assumed.

\section{The major issues in the ACI}

The ACI mangrove organization has faced a number of conflicts that are historically rooted within Tongke Tongke's traditional power structure (Friedberg 1977). These perceived issues take the form of credit taking, power grabbing and social and political exclusion. The members of the ACI mangrove organization come from diverse background and social status, and among them are Bugis landowners, boat owners, laboring fishermen, farm laborers and middle-aged inland fishermen who left the organization due to a perceived unfair advantage of some member over others. ${ }^{4}$

\section{Issue 1) Taking the credit}

There are different accounts of the founding and advancement of the ACI mangrove organization. The deputy head of $A C I$ claimed that it was he who initially united the different mangrove cultivators under the name $A C I$. Mr. TYB, ACI's former head, was deposed by other members due to perceived credit taking, money laundering and one-person domination. Former ACI members stated that Mr. TYB illegitimately claimed to have planted and nurtured the mangroves, as well as having begun the ACI mangrove organization. By contract Mr. TYB said that it was he who was responsible for founding the organization since he introduced ACI to government officials, NGOs and donor agencies. Two former members of $A C I$, Mr. TPD and Mr. BMBNG, also claimed responsibility for the mangrove cultivation scheme and the alliance with government officials. They argued there is no need to maintain the decadent ACI organization of the present since the older generations are very well known and respected by others, without ACI. Moreover, Mr. TYB was thought to have stolen the money given to the organization for experiments in initiating mangrove enclosed aquaculture ponds. Mr. TYB was assumed to have bought a boat with the money, of later renting it to other members at a discounted rate to gain income.

Mr. ZNDN, the present deputy head of ACI, claimed that Mr. TYB was not elected by the ACI members, but he was simply chosen by government officials because of the officials' conviction of his effort and dedication to ACI. Moreover, according to Mr. ZNDN, Mr. TYB did not plant the mangroves during the 1980s; he started planting a minute portion of Tongke Tongke's mangroves only after the village had been

\footnotetext{
${ }^{4}$ Tongke Tongke's sea ponggawas are boat owners who venture to sea with the laboring fishermen (sawi) to fish, whereas the land ponggawas are land owners and intermediaries who remain on land to market the catch and provide funding, logistics and capital to the fishermen. In return the fishermen are expected to store their catch to the land ponggawa. In most cases the land ponggawa loan money to fishermen to acquire boats and/or boat motors. The loan serves as a contract between the ponggawa and the fishermen, payable in installments within unspecified time frames as long as the fishermen remain the ponggawas' clients. Hence, decisions over the budget, equipment and fishing locations are largely dependent upon the ponggawas. In Tongke Tongke there are more inland fishermen who sell their catch in the local market than those working as laboring fishermen or sawi. The relation between ponggawa and sawi is marked by relations of power and hierarchy that benefit both parties and are common in coastal communities across Indonesia.
} 
awarded the Kalpataru environmental award. "If now Mr. TYB has a small plot of mangrove forest it is because he was given a bit by Mr. BDRDN's family in the past" stated Mr. ZNDN. But the facts are not fully resolved: when I spoke to Mr. TYB, he claimed that he not only cultivated and nurtured the mangroves, but also motivated others to plant mangroves as well. Mr. AKBR and Mr. BAKR both said that Mr. TYB earned a living from collecting crabs and hermits before the late Mr. BDRDN endowed him with a small plot of mangroves and an aquaculture pond. Mr. AKBR and Mr. BAKR also stated that Mr. TYB planted a small mangrove plot subsequent to receiving the Kalpataru award.

It was in the early 1990s that Mr. TYB began traveling around Indonesia representing Tongke Tongke at the government level, disseminating information about Tongke Tongke's community based mangrove cultivation scheme. In 1991 the Forestry Minister came to Tongke Tongke. In 1995 Tongke Tongke received the Kalpataru or the National Environmental Award from the President of Indonesia, with Mr. TYB acting as the representative to meet the president. In 1996 the Minister for the Environment came to the village to pay Tongke Tongke's mangroves a visit. Mr. TYB's role as Tongke Tongke's representative fueled jealousies among ACI members, leading to protests, his dismissal from position as head, and the cancellation of Mr. TYB's scheduled appearance in Japan in the year 2000. The mangrove cultivators stated that when Mr. TYB was about to leave for Japan, the mangrove cultivators staged a protest in front of the regency head's office demanding that he be replaced. No representative from Tongke Tongke went to Japan, and Mr. TYB stepped down and was replaced by the land ponggawa Mr. ALMDN and the organization's deputy head Mr. ZNDN through election by the ACI members. Nonetheless, albeit different stories surrounding the founding and founder of ACI, its deputy head, its former head and its former discontented members all stated the importance of forming an alliance to protect the fruits of their labor. Hence, the collective needs of both the ruling family and the community members are still translated into conservation efforts.

\section{Issue 2) Misuse of power}

Subsequent to receiving the Kalpataru award, funding and infrastructure development projects from government and donor agencies began to pour into the village. In 1996 a mangrove seed trade with the other provinces began to flourish, with government officials acting as the intermediary. This year was also the year of the 'boat incident' according to Mr. ZNDN, the present deputy head. The Department of Marine and Fishery Resources of the regency and provincial level gave the ACI organization a state-of-the-art fishing boat. Although the boat was recorded within $A C I$ 's inventory list, Mr. ZNDN claimed that it was monopolized by Mr. TYB and his relatives. ACI members, among others Mr. BAKR, Mr. AKBR and Mr. AHMD, said that Sinjai's Marine and Fishery Resource Department gave the village the boat for communal use by the ACI members. Mr. BAKR also remarked that "we see Mr. TYB's son going out to sea with this newly painted boat, and when we met an official from Sinjai's Marine and Fishery Resource Department, he stated that the village was awarded a boat through Mr. TYB." The boat story reinforced a view that Mr. TYB undermined his own credibility as a leader and undermined trust in him to lead the collective effort to protect the mangroves. Dissatisfaction did, however, strengthen the resolve of members to continue their work.

Mr. TYB argued the boat was rented by his son at a discounted rate from the Regency's Marine and Fishery Resource Department, since they were being generous to the ACI organization and were interested in empowering the fishermen in Tongke Tongke. But when interviewed, executives and staff from the Department said they were unsure of the boat's origin. They said it was the initiative of the Provincial Marine and Fishery Resource Department - the next level down in the hierarchy of government. On questioning one of these officials, no light was shed since the interviewee said the incident had occurred before his time. Despite his very visible role as the ACI mangrove leader, this issue was dealt with by demoting Mr. TYB from his position as head. The villagers' ability to do this and his abdication suggested responsibility, cohesion and social justice within the group, even though evidence of his misdemeanours was never proven by the government. In this case at least, Tongke Tongke social institutions and social capital were sufficient to ensure that collective effort at protecting the mangroves and the organization were not undermined.

\section{Issue 3) Social exclusion}

In 2004 Sinjai's Forestry Department also intervened through its GNRHL program, concerned with land and forest rehabilitation. Included within this program were initiatives for conserving and reforesting Indonesia's coast through mangroves cultivation. The program in Tongke Tongke boiled down to giving funds to ACI members for planting new mangroves, and also for demonstrating novel techniques for selective cutting and mangrove cultivation. ACI's deputy leader Mr. ZNDN was responsible for recruiting village laborers to carry out planting. He was also the person responsible for distributing wages to these laborers. He remarked that within the GNRHL program "it is the government officials who decided on technical matters such as how much and which of the land should be rehabilitated and how this rehabilitation should proceed"...but..."there is never a clear message concerning the direction of the program, the structure of the program, the funding for the program, and the opportunities for participation in decision making". He also said that ACI members were reluctant to participate in the GNRHL. Hence, it was up to the ACI leaders to administer it in Tongke Tongke. 
The GNRHL program led to some disputes and polarization of views among ACI members. It was ultimately unsuccessful (Amri 2008). Members claimed that government officials simply endowed $A C I$ 's leaders with money. It was then up to these people in ACI to find suitable villagers to (re)plant the mangroves and pay them. "Government officials simply stated to Mr. ZNDN that the laborer be paid a certain amount of money on a daily basis, but it was really up to Mr. ZNDN to distribute the money and organize the workers" said Mr. TPD, a former ACI member who refuses to remain in ACI. In addition, Mr. TPD, who in the past planted the mangroves for the GNRHL program, said "if Mr. ZNDN, his close friends and the government officials held programs to plant mangroves, we're never informed of the activity and the actual amount of money which we should receive as laborers, when we should receive it, and how much money the leaders of ACI are actually receiving from the government". He said community members "get much less than they're supposed to receive from Mr. ZNDN" and when villagers "asked the official from the Forestry Department he said they were supposed to receive this much, but in fact they only received that much". Mr. TPD concluded that "nothing is ever clear and transparent" and they're "now sick of working with the present deputy leader Mr. ZNDN." Rather then being passive and powerless, community members are weighing up the implications of government policies and programs. In some cases, as this one, villagers align more with government discourse (restore Tongke Tongke's mangroves) than with the ACI leadership (imbalanced payments for that restoration). When participating in schemes, villagers align bits and pieces of funding and group projects that pertain to their needs and interests whilst protesting a power inequity and a lack of information.

\section{Joint decision making and consensus across government levels}

As elaborated above, some government officials are genuinely concerned about the depletion and degradation of coastal resources. They see the need for protection through collective governance and comanagement. This, according to officials, can be facilitated through consensus and joint decision making in policy and program formulation (Ostrom 1990). Reaching concensus occurs across the various levels of governance and with communities. According to Mr. BDMN, the head of Sinjai's Marine and Fishery Resource Department, "government officials hold yearly meetings with community members to incorporate local aspirations, promote participation and encourage sustainable development through collective action". These meetings are called MUSRENBANG or Musyawarah Rencana Pembangunan. Fakih (1996) noted that in the name of national growth, development and prosperity, the Suharto administration asserted its legitimacy in centrally administering the governance of natural resources, leaving a much reduced opportunity for local groups to reap benefits from them. There was intolerance of pluralism and dissent, widespread political intimidation, corruption and nepotism, displacement of responsibilities and ecological devastation (Moniaga 2000; Galdikas 2001). The post-Suharto decentralized administration considers social inclusion and political stability through institutions like MUSRENBANG to be vital in achieving sustainable development goals (Rohdewohld 1995). Nonetheless, Thorburn (2001) noted that the decentralized public administration system leads to a number of issues and challenges. Since the regency government is assigned most of the responsibility for running government matters within the district and village level, the provincial governments responsible for coordinating the various regencies are often subverted by both the national and regency governments. Moreover, regional autonomy and financial decentralization often leads to the regency's obsession with local revenue generation over long-term social and environmental costs. In the light of regional autonomy, the regency head or Bupati possesses tremendous political power. This can encourage the misuse of power, leading to corruption, collusion and nepotism. Regional autonomy leads to the domination of local power by hereditary elites who combine both traditional indigenous authority and state power at the regency, district and village levels (Thorburn 2001). Thorburn (2001: 10) further noted that "there are very few checks and balances on these sorts of political power [and] there is concern that decentralization could be encouraging the creation of authoritarian states within a state".

Government officials suggest promoting social inclusion by aligning and aggregating diverse needs and interests (Kurian 2000). Figure 4 shows how interests are aggregated in policy and program planning. It is based on inputs from government officials at the provincial and regency levels during interviews. A version is also commonly found in government posters hanging in Sinjai's government offices. During an interview, the head of Sinjai's Marine and Fishery Resource Department, Mr. BDMN, stated the need to encourage tudang sipulung or consensus making in regard to policy making, although the terms of engagement are hardly populist ones, and minimally participatory: "the community members will follow government rules and regulations when they are drafted together with the community" he said.

An official from Sinjai's Forestry Department, Mr. NWR, repeated the same official discourse "the need to develop a common vision and mission with community members when promoting participation, social inclusion, political stability and continuity in government policies and programs". An executive from Sinjai's Forestry Department, Mr. SRJDN, remarked that "every year through technical coaching and consultation meetings we communicate our vision and mission, and state our limitations...this is done to acquire commonalities of vision on policies and programs and to gather aspirations from the bottom." Hence, according to these government officials, social inclusion, political stability and the sustainability of conservation programs can be facilitated through aggregated interests and consensus making in policy and program planning within MUSRENBANGS. As well, through MUSRENBANG government officials believed 
that wide-ranging representation in consensus making can be facilitated. Despite these noble intentions, the social and ecological landscape is marked by multiple management regimes, and the complexity of local contexts cannot be made subservient to a certain form of natural resource governance (Steins 1999). Moreover, egalitarianism and consensus making processes neither guarantee the lateral relationship one imagines, nor do they warrant the emergence of social reciprocity and social validation that are required for incorporating cultural sensitivity and environmental consciousness into people's thoughts and imaginations (Soja 1989; Light 1998). In the brief examples reported above, it was clear that government initiatives were not always understood by locals, allowing ACI leaders to direct them personally.

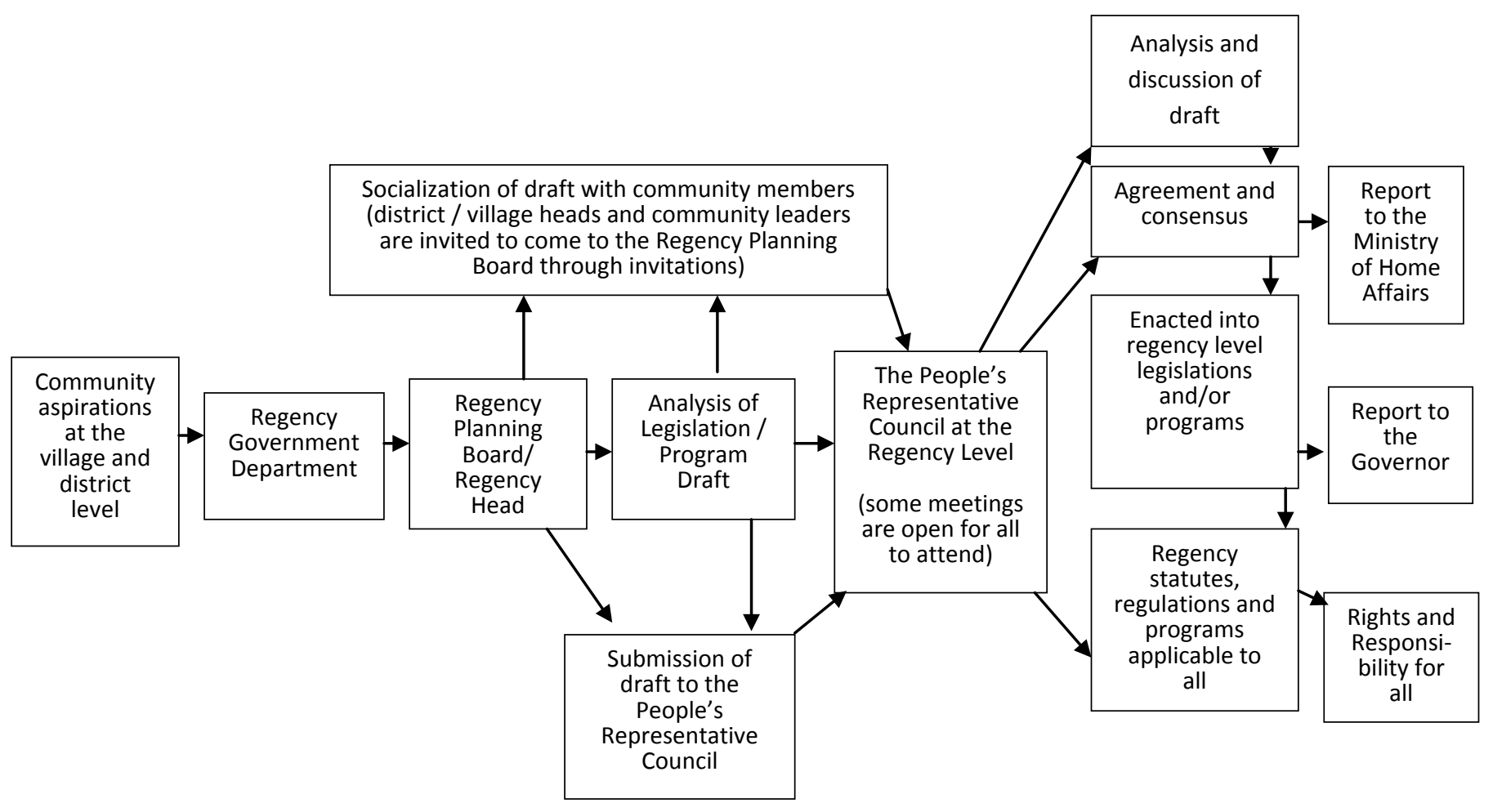

Figure 4: Consensus building for policy and program planning in Indonesia

\section{Process and mechanistic issues in representation}

Multilevel governance of resources, therefore, requires adequate representation of individual and group interests. But representation of these interests and viewpoints, whether by community leaders or government officials, may be difficult to assure (Rourke 1986). Process issues include narrow selection of representatives, and withholding of information and knowledge. There are also language barriers and issues of attendance at meetings: "what may appear to be a consensus is in fact the more or less one-sidedly enforced outcome of the dominant power relations under the often deceptively un-problematical form of an agreement producing communicative interchange" (Meszaros 1989: 28). This can be a top down directive from the regency or a one party decision carried out by village officials and elites, an example being a property and commodity tax supported by Tongke Tongke's village officials. In order to raise local revenues, officials taxed community members for owning properties such as boats, bamboo huts, aquaculture ponds and livestock. During Tongke Tongke's biannual budget allocation meeting, officials from the village planning board noted that community members avoided these taxes. They asserted the need to employ debt collectors for explaining and ensuring tax payments. Villagers such as Mr. RHMN and Mr. SLMN noted that "suddenly the village officials informed the villagers of the need to pay taxes for their land, ponds and houses." Needless to say, this was unwelcome.

Tongke Tongke's community leaders and ACI members, including sea ponggawas Mr. MSTMN, Mr. BMBNG and Mr. MSTF, mentioned that community participation in policy and program planning for sustainable coastal resource management was very limited. The mangrove forest rehabilitation program, the sustainable aquaculture farming program and the fishery monitoring program in the Bay of Bone lacked community input. Community leaders felt they were unrepresented, despite their status and ACI membership. One said "those who know about the programs and are involved in planning and implementations are only those who interact with government officials, namely the village officials and deputy head of ACI." In 
addition, they feel policy and program planning was marked by a top down and one way flow of information from representatives to the represented, thus denying voice, identity and agency (Dyrberg, 1997). In response, the deputy head of Tongke Tongke's ACI, Mr. ZNDN, stated that "it is too formal for the community if they hold a meeting and say that it is a meeting. Often times the community does not want to come if they are invited to a meeting". He also argued that meetings with government officials were usually conducted with protocols, esoteric language and reverence towards the hierarchy within the bureaucracy. Community members preferred to refrain from these meetings because they felt out of place and dislocated from their surroundings. Villagers avoided associating with the culture and circumstances surrounding these meetings. Moreover, villagers in Tongke Tongke spoke a local dialect, Bugis Pesisiran, whereas meetings were held in Indonesian. As well, the present local government is somewhat distant and detached from community members, whereas the need to adhere to the bureaucratic culture and positivistic mindset for objectivity, confidentiality and security is great.

\section{Implications for power sharing}

Power is defined as "the capacity to introduce change in the face of resistance" and can be classified into utilitarian, coercive and persuasive forms (Etzioni 1968: 670). Utilitarian assets include economic possessions, technical-administrative capabilities and labor power. Coercive assets are the weapons, installations and manpower which the military, the police, the court and the government use. Persuasive power is exercised "through the manipulations of symbols, such as appeals to the values and sentiments of the citizens" (Etzioni 1968: 331). Normative assets include the symbols, values and sentiments which are used for normative control (Etzioni 1968: 670). Normative control is defined here as persuasive power and/or influence. Persuasive power is exercised "in order to mobilize support and penalize those who deviate by ex-communicating them" (Etzioni 1968: 331). Consequently, persuasive power rests in the interpersonal ties which bind the members of a unit to each other. With regard to natural resource governance, the narratives from Tongke Tongke suggest that these various sources of power influenced groups and individuals in multidimensional ways, as other studies have shown (Nuijten 2005).

Tongke Tongke's mangrove governance illustrates that, following Etzioni, "while persuasive power may support normative control, it tends to neutralize normative control in the absence of monitoring and enforcement". This "occurs macroscopically when a sub collectivity is mobilized against societal leadership" (Etzioni 1968: 336). But there are difficulties in mobilizing an un-mobilized group when confronted by "the apathy institutionalized in social bonds" (Etzioni 1968: 337). This occurred during a conflict in the community between two groups, one of which, the former ACI members who refused to remain in ACI, mobilized the persuasive power of the community members. The disgruntled ACI members encouraged others to depose its former head, Mr. TYB, and then former ACI members mobilized others to dispute the current vice head's unfair domination of the organization and its associated rewards. In 2000 JICA and the regency government were about to send Mr. TYB to Japan to tell the story of his village people and the mangroves. Nevertheless, the other ACI members protested. Mr. MSTMN, a former member, stated:

When Mr. TYB was about to go to Japan I got the other ACI members to sign a petition, and I and Haji BAKR round up the other ACI members who were also frustrated with Mr. TYB, and we walked down to the People's Representative Council and met the Bupati, and asked the Bupati that Mr. TYB be ousted from his chair. The Bupati kindly received us, and stated that he would speak to the people in the Forestry Department and the YTMI NGO to facilitate change. Then we held a demonstration in front of the Council's building, and I even got an orator from Hassanuddin University to speak with me in front of the crowd and the local TV station to cover the event since I am an activist and I have close relations with individuals from NGOs, the local press and the television. If Mr. TYB does not leave ACI and goes to Japan, we will cut down all the mangroves.

This is a good example of the power of the mangroves. The threats show how angry members had become at Mr. TYB's betrayal as a poor representative. I asked Mr. MSTMN if he would have cut his mangroves should Mr. TYB have gone, but he said "we need the mangroves and we have to preserve the mangroves because without it we will be swamped with salt water". Hence, the protest over Mr. TYB's domination did not result in the villagers' cutting the mangroves. This suggests that the various forms of power "tend to slant compliance in its own direction which is partially incompatible with that of the others" (Etzioni 1968: 353). Hence, sources of power tended to neutralize each other (Etzioni 1968). Multi-dimensionality exacerbated plurality in decision making: such that "the controlling over layers of several societal units is shown to mix various kinds of power without giving clear priority to one kind" (Etzioni 1968: 355). There was contingent emergence and dissipation of multiple management regimes in Tongke Tongke's mangrove governance and, to a certain extent, this created a space for the distribution and sharing of power among wider community user-groups and key members of ACI. 
The use of power by community members, along with the need to involve higher level authority, depended on timing, perceived urgency and the pace of change. Etzioni noted that "the less overdue and the more rapid the transformation of a societal structure, the less need there is for order enforcing organization and the more slow a transformation, the greater the need for such organization whereby power and force are involved" (Etzioni 1968: 364). Despite the present lack of initiatives from the ACI mangrove organization leaders, the incident suggests that power 'negotiations' between the various members contributed to a dynamic and ongoing protection of their mangroves.

\section{Protecting natural resources through commercialization and conservation policies}

After 1997, the regency government protected Tongke Tongke's mangroves through legal regulations for their use, allocation and governance. In 1997 Sinjai's Forestry Department enacted Regulation No 23/1997 (1997). This stipulated that logging and destruction of the forest area will be met with a fine of Rp500 million (US\$ 53,155 today) or a maximum of 10 years in prison. The above law is contradictory to Local Regulation No 09/1999 (1999). Local Regulation No 09/1999 stipulates that 50 meters inland from the coast (i.e. from the reach of the highest tide) selective cutting of the mangroves is permitted, provided that users receive a permit from the head of the region or the extension officer from Sinjai's Forestry Department. A breach results in three month's detention and/or a fee of Rp50,000, or US\$ 5.30 (Dinas Kehutanan, 2002).

ACI members and villagers generally consider these conservation statutes to be authoritarian and topdown. The extreme contradiction they present causes the villagers to perceive them as trivial and nonbinding. Nonetheless, they also welcome them. They simultaneously detest and respect the statutes promulgated by government officials. On one hand, the ACI members stated that government officials are encroaching on their mangroves and taking the credit for the members' cultivation initiatives. On the other hand, the government is also validating these members' identity and labor, whilst protecting their material and symbolic interests and providing them with a place to differentiate themselves from others.

According to the head of Sinjai's Regency Planning Board, Mr. SYMSQMR, awareness for protecting local coastal resources can actually arise through their commodification and commercialization, not only through conservation. The commercialization of local coastal resources can take many forms, including promoting eco-tourism, processing and marketing local fish products, and selling locally made handicrafts. Hence, according to some officials, stimulating ecological awareness for protecting local coastal resources is grounded within the need to commodify and commercialize local coastal resources for improving social welfare. According to Mr. SYMSQMR, the mangroves' ability to attract funding from the international community stimulates awareness and motivation for their protection. The Samataring district head, Mr. ADNR, remarked that "if we try to promote our mangrove to countries outside Indonesia, foreigners would automatically come here...we can try to make something out of our mangroves, such as an eco-tourism site, so the mangroves can provide the villagers with income". An official from the Regency's Forestry Department, Mr. SN, said thinks there is a need to transform Tongke Tongke's mangroves into a bank from which villagers can obtain financial security. In promoting ecological awareness, the perceived need for attaching commercialized value is evident through policies and programs that combine sustainable development initiatives and natural resource commercialization efforts (Bebbington et al. 2007; Beck 1999, 2000).

With generally benign intentions, the government officials involved in this study strove to integrate development, sustainability and ecological education through initiatives such as the construction of mangrove enclosed aquaculture ponds, a ban on destructive fishing, and the protection and utilization of Sinjai's reefs as fish breeding grounds. Mr. BDMN, the head of Sinjai's Marine and Fishery Department noted that "the mangrove enclosed aquaculture pond was a project involving the fishery and forestry department and the community to encourage both mangrove conservation and economic development". The land which is permitted for selective cutting is 500 meters from the coast, where the composition is 60\% mangroves and $40 \%$ ponds. These ponds are expected to produce milkfish (Chanos chanos) that are sold locally. In Sinjai, the wood and twigs from the mangroves are sold locally for firewood, whereas the seeds also have a value and a price. The leaves are sold within the village for feeding goats and livestock.

Nonetheless, the Samataring District head, Mr. ADNR, also acknowledged that commercializing local coastal resources can discourage ecological awareness and exacerbate over-utilization. When coupled with private profit motives, he said, the presence of investors, commercial values and potential market demand for local coastal resources can discourage environmental sensibility. This contradictory opinion suggested that some officials are aware of the need to venture beyond utilitarianism in facilitating ecological awareness, devolution of responsibility and social cohesion. Nonetheless, officials seem to have trouble stepping out of the bureaucratic induced rationality and the perceived need for attracting funding. But the presence of funding does not necessarily deter the emergence of social and ecological awareness. Community members and government officials are weighing up the implications of government policies and programs in the face of complexity and change. 


\section{Capture by commercial imperatives: the "bat incident"}

In the case of the mangroves, it was when symbolic and authoritative resources began flowing from them that the majority of the resource users became keen on protecting them. However, when ACI's former head utilized accumulated private gains and dominated the organization, the $A C I$ members also perceived the mangroves as a probable instrument of domination and marginalization, over which power is wielded. Multiple social constructions and multiple attachments to the mangroves therefore underlie Tongke Tongke's conservation efforts. These attachments go beyond utilitarianism and resource commodification. Space can be created for multiple attachments to flourish; nonetheless, this space can also be deterred, undermined and curtailed due to a power imbalance and complexity within social and ecological landscapes. An example relating to Tongke Tongke's trade in bat species suggests how space can be curtailed due to the complexity of local bat commercialization practice involving merchants, bat hunters, local police officers and government officials from the village and regency's forestry department.

Sulawesi has 62 species of bats, including some large species of fruit bats (Pteropodidae). As the local people are Moslem, they do not eat them themselves but can sell them to the North Sulawesi Christians and Chinese, where they are a food source. In the year 2001 bats were starting to thrive among the local mangroves, and villagers were hunting them down by the thousands and selling them to traders for consumption in North Sulawesi. Buyers include merchants from the regency and the province, as well as extension officers from Sinjai's Forestry Department and law enforcement officials such as the local land and water police. In 2002 the "bat incident" occurred. Intermediaries all over Sinjai and South Sulawesi came to collect the bats that were hunted in large numbers by villagers in Tongke Tongke. There were disagreements and disputes among ACI members, villagers and government officials over the terms and conditions for bat hunting, over the Forestry Department's roles in protecting the interests of the members and the villagers, and over profit sharing from the sale of the bats.

The Regency's Forestry Department provided the ACI members with some consolation by issuing a statute declaring that the bats can only be hunted on certain months of the year with permits from the Regency's Forestry Department and the village head. Moreover, the Department also limited the number of intermediaries who were given the permit to sell Tongke Tongke's bats. According to the village head and $A C I$ 's deputy head, the Forestry Department ultimately granted everyone who sought permission a hunting permit regardless of season or origin. The village head and $A C I$ 's deputy head also stated that everyone who sought permission to be an intermediary was granted a permit regardless of season or origin. They also said the intermediaries had to pay a certain amount of money to the officials to acquire the permit and to share the profit with officials from Sinjai's Forestry Department, in order to assure continued hunting. The bats were then hunted incessantly, and several years later, the remains of the colony have disappeared from the mangroves.

Recriminations began. Villagers claimed that the bats migrated elsewhere to avoid being hunted. Officials from Sinjai's Forestry Department said they had tried hard to minimize the number of legitimate hunters, poachers and traders. Nonetheless, hunting continued. Government officials also claimed that village officials and the $A C I$ leaders refused to take action and continued issuing hunting permits. In an interview with Mr. NWR, from Sinjai's Forestry Department, he blamed village officials who continued to issue permits, and deemed them to be poor managers of the common resource. According to the village officials (and apparently few of them were hunters) it was the government that was negligent. In the midst of this suspicion and mistrust, the bat hunting permits became synonymous with efforts at profit accumulation and group monopolization. The permit and profit sharing system required by the regency and village officials, when compounded over time and across the landscape, colluded to destroy any opportunity for bat conservation. Opportunities for commercialization were also lost, so there were no winners.

By requiring permits and profit-sharing from the trade, government and village officials encouraged a utilitarian attachment to the bat colony (Zey 1992). Moreover, by providing permits to hunters, officials did not encourage holders to identifying with the bats or their habitat, and commercialization of the colony meant less or no attention given to habitat and species health. As a result hunters converged, and aligned with the social construction promoted by the government and village officials. Hunters also perceived the government and village officials to be the primary agent holding decision-making power over the use, governance and social construction of Tongke Tongke's bats. In an interview with the Samataring District head, Mr. ADNR, he said holding a bat hunting permit became so important to the point that there was no discretion over the welfare or long term management of the bats themselves. Mr. ADNR also mentioned the presence of a 'cultural crisis' (krisis kepercayaan) in Indonesia more widely; this refers to the lack of trust by villagers towards the government. In my interviews there were no voices that spoke out for bat conservation, and people were reluctant to revisit this event. Some bat hunters were reclassified as poachers, depending on whether their permit was legitimate and who they purchased it from. The bat hunters, who were mostly non $A C I$ members, created a paradox for the ACI. Hunters wanted the money from selling the bats and ACI obtained some revenue from permit sales. Nonetheless, at the same time the ACI members also denounced the bat hunters who acquired permits from government agencies. In my interviews, it was clear that the ACI leaders wielded authority by excluding some hunters and permitting others, depending on the circumstances these leaders saw as proper for their personal interests. 
This "bat incident" exposes the mistrust between all those engaged. The permit system overrode common sense and disconnected local management from the conservation of the bat itself. Other 'inhabitants' of the mangroves such as crabs and mollusks can easily be hunted too, but are only consumed within the village and the district. The bats were of much higher monetary value and not eaten by the locals. Nevertheless, even though contention and suspicions were rampant among the ACI members and the bat hunters, the motivation to protect and conserve the mangroves remained intact and was even solidified by the events that took place in the village.

\section{Overemphasis on regulatory measures}

Executives from Sinjai, including the head of the Regency's Planning Board, noted the need to enforce the regency's agreed-upon statutes which prohibit the logging of Tongke Tongke's mangroves. In the absence of these statutes, some executives fear the mangroves will be degraded or cut. The vice head of Sinjai's Forestry Department, Mr. SRJDN, remarked that

...it is necessary for community members and government officials to enforce the agreed upon statutes which prohibit the cutting of mangroves...villagers are poor and the minute there is a demand for aquaculture produce or wood they will cut their mangroves and convert it to ponds.

He correlated the sustainable governance of coastal resources with several variables. The first is the conservation of coral reefs, mangroves and the coastal land through collective efforts. The second is the community members' adherence to statutes and regulations that are collectively drafted by government departments, the House of Representatives and community members. The third is the presence of village institutions for creating and enforcing agreed upon statutes towards the sustainable use of local coastal resources. The vice head of Sinjai's Forestry Department, Mr. SRJDN, noted that "if, along with government departments, the villagers make rules and regulations of what is allowed and not allowed and how these rules should be monitored and enforced, they will then follow the rules and see that the rules are being carried out fairly among all of community members".

Mr. RSMN, the director of the Indonesian Self Growth Foundation, remarked that "government officials like making new statutes and laws while anticipating and incorporating things into them; if the villagers should revolt, government officials can easily state to them look it's in the law, we can't do anything about it". Hence, laws and regulations also reduce the officials' vulnerability to dissent and thus protects them. Various government departments in Sinjai (e.g. the Forestry Department, the Department of Marine and Fishery Resources and the Regency Planning Board) showed great pride in Tongke Tongke's mangroves and the statutes that are drafted to protect them. Government officials print and distribute pamphlets about the mangroves and its statutes to show their achievements to overseas visitors.

In reality, even when there are demands for fishponds and wood, community members refuse to clear and cut them. The vice head of Tongke Tongke's ACI mangrove organization, Mr. ZNDN, stated that "when the Department of Marine and Fishery Resources held a program to build aquaculture ponds among the mangroves outside the green belt areas, many of the mangrove owners refused to collaborate because they fear the department and the former head of ACI were collaborating to take over and sell our mangroves". He also said that "we do not want to sell or convert our mangroves to ponds. This is our mangroves and we want to keep it as a mangrove forest for our protection, safety and pride." Hence, the good name of the village and the mangroves' function as a buffer against tidal waves, motivate community members to align with the collective good, and to protect the local mangroves. When participating in government policies and programs, villagers align the bits and pieces which pertain to their needs and interests whilst jettisoning others.

\section{Promoting social responsiveness and ecological sensibility}

Tongke Tongke's mangroves were initially planted to protect the village from tidal waves, and to create new land and space. The new land is regarded as private property by the villagers despite being in the state-owned littoral zone and can be sold, rented or converted to ponds in times of need and hardship. Over time, community members have been inclined to plant as many trees as possible to hold on to the land against immigrants and outsiders. Despite being privatized, the discourse underlying the governance of Tongke Tongke's mangroves points to the need for collective management and resource conservation. ACI's deputy head stated that

...in the beginning community members started to plant mangroves because they wanted to acquire land and build aquaculture ponds, but since the mangroves can protect their village and promote the name of the village all over the world, they do not want to cut down the mangroves anymore. 
This is evidence of altruistic conservation. The regency government also played a significant role in promoting the organization's name and spreading the success story of Tongke Tongke's mangroves. Local officials enjoyed having their people's achievements praised, their region recognized and their project funding secured. An unwritten rule emerged within the village and the regency, namely that the mangroves were to be managed collectively and that all community members and government officials were endowed with the responsibility to protect and conserve them. This reinforced the cultivators' attachment to the mangroves and provided them with a sense identity, recognition and differentiation. At the outset the function of the mangroves was for protecting the coast and the village from wave encroachment. This changed as the mangroves were increasingly seen as a source of individual and group recognition. Moreover, as time passed the mangroves became a symbol of collaboration and stewardship whilst reconnecting local villagers to the social and ecological landscape. In an informal discussion, Mrs. SWRN, the widow of a sawi or laboring fishermen stated that "the people in the ACI organization have done much for the village, including protecting our village, making us well known everywhere, getting important people like the minister, governor and regency head to come here and help build the village". Hence, the symbolic and authoritative resources acquired by the ACI members were perceived as legitimate by non-members in the village. Conservation values are safe, since the mangroves provide property and power for the cultivators, and the mangroves became a source of pride and recognition for the community members in Tongke Tongke.

Nonetheless, the ACI mangrove organization is also rife with conflict and contention, as I have shown. Interestingly, these disputes strengthened their attachment to the land and the local mangroves. This strong attachment also led to increased motivation for protecting the resource. Cultivators and community members were grateful to the ACI organization for putting Tongke Tongke on the world map. The villagers all took pride in the fact that Tongke Tongke is known nationally and even internationally for its mangroves. In relation to the regency government's effort at transforming Tongke Tongke's mangroves into a park, all of the ACI members interviewed stated that government officials were keen on taking the credit and turning ACI's mangroves into the regency's park. Nonetheless, despite their resentment, cultivators and community members were proud of the attention they received from government officials, and villagers and government officials all wanted the same outcome, namely to conserve Tongke Tongke's mangroves.

Identity validation and social recognition have a number of implications for social responsiveness and ecological sensibility for sustainable governance (Honneth 1999; Horkheimer 2002; Bookchin 1994). The case of Tongke Tongke's mangroves suggests that identity validation and group and individual recognition are important for promoting social responsiveness, ecological sensibility and the collaborative mentality. This act of validation and recognition in turn precipitated a reflective capacity, a sense of potency, and a need to encourage obligation among cultivators and community members. This also precipitated active participation for protecting the local mangroves. An example of this was when Mr. ZNDN, the deputy head of ACI, stated that "the people of Tongke Tongke initially wanted to turn their mangroves into aquaculture ponds, but when they saw that the mangroves could protect the village and brought fame to the village they started thinking and realizing how important the mangroves were for themselves and others." So, although the cultivators' attachment to the mangroves can be altered by external interventions such as policies and institutional measures, for these to have profound impacts they would have to be negotiated in the historical context, and within local practice and circumstances.

The ACI members recognized and acknowledged the roles that villagers and government officials played in providing them with identity, recognition and authority, hence when Sinjai's Forestry Department decided to transform the community's mangroves into a national park, the ACI members were proud of their park and happily aided in conserving the mangroves although resenting the encroachment by government officials. Both ACI and community members were very protective of the local mangroves and would not allow others to undermine their collective effort in protecting them. An example of this was when the ACI members mobilized, deposed and socially sanctioned its former head, Mr. TYB. Mr. TYB was deposed because he was "dominating the liaisons with government officials and corrupting the donations which flow into the organization". Another example was when the anti-ACI villagers encouraged the villagers to protect the mangroves and provided them with identity and recognition. Despite differences in interests, this acted as a platform for resource protection and enhanced the conservation value of Tongke Tongke's mangroves.

The idea of imagination-building comes from Wenger's Community of practice: learning, meaning and identity (1998), and is a reminder that constructions of identity and imagination are shaped by social practice and patterns of engagement. Tongke Tongke illustrates this. The imaginative force here is the recognition of the collective good that is largely unseen by locals but appreciated by outsiders. An example of this imaginative force was when Mr. MSTMN, a mangrove cultivator who saw himself as protector of the village, said "the village needs me and my mangroves, what will the villagers do without my mangroves?" These discussions on the ACI mangrove organization suggested that local practices were multi-dimensional and not exclusively controlled by external interventions. The multiple constructions and associations underlying the mangroves suggest multiple management regimes operate, beyond utilitarian and commodification discourses alone. In Tongke Tongke social institutions in the form of kinship ties, mutual recognition and identity validation were present (Bourdieu 1991), and these motivated individuals to protect the local mangroves in the absence of monetary and utilitarian incentives. This became the fabric for the collective governance of mangroves. 


\section{Private ownership and collective governance}

The collective governance of natural resources is associated with the need for collective ownership and co-management (Ostrom 1990). The need for collective resource governance is based on the assumption that private interests are contradictory to collective needs. Ostrom's CPR theory suggests that collective governance can be facilitated through common ownership, consensus and joint decision making (Ostrom 1990). The Tongke Tongke case suggests that private ownership of the mangroves is not contradictory with protecting them. Mangrove ownership by local user groups led to their protection. The perceived need to protect the mangroves and is so great that villagers refuse bad judgments which can undermine collective management. An example of this was when Sinjai's Marine and Fishery Resource Department collaborated with Mr. TYB to advocate the construction of aquaculture ponds. The villagers refused, saying that Mr. TYB, the former head of ACI, was misusing his power, subverting the other ACI members, and undermining efforts at protecting the mangroves. Social constructions underlying property and user rights influenced the social and ecological responsiveness of natural resource protection.

In The Tragedy of the Commons Hardin (1968) assumed there are only two choices to natural resource management, either through privatization or state intervention in which public ownership prevails. The failure to promote socially viable and ecologically sustainable decision-making leads to the argument for public ownership by the state. Nonetheless, the privatization of Tongke Tongke's mangroves has co-existed with social capability and public obligation for their protection and conservation. Noting Hardin's narrow categorization of natural resource management, Ostrom (2007) remarked that multiple management regimes are present and that Hardin undersold the presence of social institutions created through mutual engagements. Nonetheless, what Ostrom (1990; 1993; 1994; 1995; 2001; Gibson et al. 2005) missed is that the anticipation of personal rewards emanating from the privatization of local resources can increase resource users' motivation for natural resource protection. In Tongke Tongke, mangrove owners are highly motivated to protect and conserve them due to the symbolic rewards (e.g. status, identity, political space) they receive from the private ownership and the collective management of the plots. Private ownership and collective management also their lead to their association with non market resources such as that of family time, social life and ecosystems, rather than market commodities. With regard to Tongke Tongke's bats, in contrast, the perplexing permit systems, the unfettered competition to catch and sell them among community and non community members, and their 'open access' nature led to the bats' association with pure market commodities.

\section{Conclusion}

Collective action for protecting natural resources cannot be maintained solely through collaboration and consensus, since contentions and antagonistic relations are present within social and ecological landscapes. Tongke Tongke's experience suggests that collective action must be contextualized within the dynamics and complexity of local settings. In democratic societies collective action for natural resource protection cannot be dictated or enforced by external agents (Habermas 1987). The concept of collective action has to make room for the differences in the resources required to change an individual (Friedman 1992; Plumwood 2002). Resource users change through their personal experience of engaging with one another and through a reflection of themselves and the social and ecological landscapes (Scoones and Thompson 1994). Changing an individual means different things among different people, meaning that the length of time and amount of resources required to change a person varies from one individual to another.

Collective action for natural resource protection is shaped by individuals acting in the social and ecological landscape. It is the transformations within groups and individuals that hold the greatest promise for the collective and sustainable governance of natural resources. Nevertheless, any intentional action by an individual will inevitably be context-dependent. Therefore, when speaking of the initiation and maintenance of collective action we are obliged to take up a position on the matter of agency (i.e. human actions) and social structural forces (Soja 1989). The need to involve others and to promote collective natural resource governance looms large in the face of Indonesia's mass environmental degradation and structural inequality. To promote participation and collaboration for natural resource protection, there is a need to provide resource users with a sense of importance and dignity that appeals to their identity and imagination (Weick 1995). Only then can individuals be actively involved in supporting the protection of natural resources. The narratives from Tongke Tongke suggest that an individual's sense of importance, recognition and obligation to act for the common good will motivate them to perform extraordinary actions beyond their everyday practice, including natural resource protection (Lacan 1999; Etzioni 2004). Nevertheless, participation and inclusion cannot take place in the absence of complex reciprocity among various groups and individuals (Giddens 1981). The principle of reciprocity suggests the mutual need for power, recognition and validation in order for social responsiveness and ecological sensibility to emerge (Harvey, 1996). The case study suggests that complex patterns of reciprocity among groups and individuals shape the discourse surrounding the mangroves and influence the barriers and enablers for participation in natural resource protection.

Undermining reciprocity can result in power imbalances, resistance, and decreased social capability (Holub, 1992; Kiros, 1985). The study suggests that when power imbalances surface, when reciprocity is undermined, and when private interests override local social institutions, suspicions and mistrust arises, 
fueling the potential for the over-utilization of natural resources (Lesser, 2001). An example of this is Tongke Tongke's bats. The emergence of space and competing discourse in Tongke Tongke requires the formation of alliances (Etzioni, 2004). These alliances not only provide identity and voice for the various resource users, they also motivate groups and individuals to mobilize and participate in the contingent restructuring of landscapes (Etzioni, 2004). Nevertheless, resistance and mobilizations are also contingent upon alignment of competing timelines and the complexity of events within the landscapes. They tend to be fragmented and diffuse.

Complex patterns of reciprocity among user groups promote attachment to the mangroves and the natural landscape. This attachment also emerged from a history of living within landscapes. A person's ties and commitment to natural resources cannot be dictated solely by institutions, policies and monetary incentives (Fararo, 1992). It is very personal and is precipitated by the person's identity, imagination and sense making (Elliot, 1999). It is dynamic and multi-dimensional, fluid, and dependent upon the complexity of local circumstances (Leuwis, 1993). The story of Tongke Tongke's mangroves suggests that when ties to the social and natural environment are rewarded with recognition, validation and differentiation, groups and individuals will feel obliged to retain these ties whilst protecting the social and ecological landscapes. And these ties also stimulate the emergence of a reflective capacity to collectively protect.

\section{References}

(2002). Keputusan Daerah No 203/2002 tentang Konservasi Hutan Bakau dan Satwa di Kabupaten Sinjai. Dinas Kehutanan: 1 - 3.

Andrianto, A. 2006. Governance brief: district governments \& poverty alleviation in forest areas in Indonesia. Centre for International Forestry Research.

Amri, A. 2005. Community participation in rehabilitation, conservation and management of mangroves: lessons from coastal areas of South Sulawesi, Indonesia. African Study Monographs, Suppl. 29: 1930 .

Amri, A. 2008. Land property rights and coastal resource management: a perspective of community based mangrove conservation in Indonesia. Conference paper, International Association for the Study of the Commons. Cheltenham: University of Gloucestershire.

Baba, H. 1994. The commitment to theory. In Baba, H. The location of culture. London: Routledge. Pp19-39.

Bappeda-Sulsel. 1998. Rencana strategis pengelolaan pesisir dan laut. Provincial Planning Development Agency, Province of South Sumatera.

Barber, C. 2002. The state of the forest: Indonesia. Washington D.C.: Forest Watch Indonesia \& Global Forest Watch.

Barr, C., Resosudarom, I., Dernawan, A., and McCarthy, J. (eds.) 2006. Decentralization of forest administration in Indonesia: implications for forest sustainability, economic development and community livelihoods. Bogor: Centre for International Forestry Research.

Bebbington, A.J., L. Dharmawan, E. Farmi and S. Guggenheim. 2006. Local capacity, village governance and the political economy of rural development in Indonesia. World Development 34(11): 1958-1976. Special issue on environmental governance edited by Simon Batterbury.

Bebbington A.J., D. Lewis, S.P.J. Batterbury, E. Olsen. and S. Sidiqi. 2007. Of texts and practices: organizational cultures and the practice of empowerment in World Bank-funded programmes. Journal of Development Studies 43 (4): 597-621.

Beck, U. 1999. Individualization and "precarious freedom": perspectives and controversies of a subject oriented sociology. In A. Elliott (ed.) Contemporary social theory. Oxford: Blackwell. Pp 156-169.

Beck, U. 2000. What is globalization? London: Polity Press.

Benda-Beckmann, F., Ed. (2001). Sumber daya alam dan jaminan sosial. Yogyakarta, Indonesia: Pustaka Pelajar.

Bookchin, M. 1994. Which way for the ecology movement ? Edinburgh: AK Press.

Bourdieu, P. 1991. Language \& symbolic power. Boston: Harvard University Press.

BPS. 2000. Statistik Indonesia 1970-2000. Online: http://www.bps.go.id/

Bryman, A. 2001. Social research methods. New York: Oxford University Press.

Cornwall, A. 1994. Acknowledging process: methodological challenges for agricultural research \& extension. In Scoones I. and J.T. Thompson (eds.) Beyond farmer first: rural people's knowledge, agricultural research \& extension practice. London: Intermediate Technology Publications. Pp 98-116.

Crotty, M. 1998. The foundations of social research: meaning and perspective in the research process. St. Leonards, Australia: Allen \& Unwin.

Dyrberg, T.B. 1997. The circular structure of power: politics, identity, community. New York: Verso.

Etzioni, A. (Ed.) 1968. The active society: a theory of societal and political processes. London: CollierMcMillan.

Etzioni, A. 2004. The common good. Cambridge, MA: Polity Press. 
Fakih, M. (Ed.) 1996. Pengakuan atas Sumberdaya alam. Yogyakarta, Indonesia: Pustaka Pelajar.

Fararo, J.C.T. (Ed.) 1992. Rational choice theory: advocacy and critique. New York: Sage Publications.

Friedberg, M.C.E. 1977. Actors and systems: the politics of collective action. Chicago: University of Chicago Press.

Friedmann, J. 1992. Empowerment: the politics of alternative development. Oxford: Blackwell.

Galdikas, B. 2001. Revenge of the little people. Pongo Quest, the newsletter for the Orangutan Foundation International. http://tinyurl.com/6s6h25e

Geertz, C. 1973. Thick description: towards an intrepretive theory of culture. In Geertz, C. The interpretation of cultures: selected essays. New York: Basic Books. Pp. 3-30.

Gibson C.C., K. Andersson, E.Ostrom and S Sivakumar Eds. 2005. The Samaritan's dilemma: the political economy of development aid. Oxford: Oxford University Press.

Giddens, A. 1981. A contemporary critique of historical materialism. London: MacMillan.

Habermas, J. 1987. Lifeworld and system: a critique of functionalist reason. Boston: Beacon Press.

Hamid H. 2002. Community conserves Tongke-tongke mangroves. The Jakarta Post, 07/23/2002

Hardin, G. 1968. The tragedy of the commons. Science 162: 1243-1248.

Harvey, D. 1996. Justice, nature and the geography of difference. Oxford: Blackwell.

Holub, R. 1992. Antonio Gramsci: beyond Marxism and postmodernism. London: Routledge.

Honneth, A. 1999. Patterns of intersubjective recognition: love, rights and solidarity. In A. Elliot (ed.) Contemporary social theory. Oxford: Blackwell. Pp184-196.

Horkheimer, M. 2002. Dialectic of enlightenment. Stanford: Stanford University Press.

Kiros, T. 1985. Toward the construction of a theory of political action: Antonio Gramsci, consciousness, participation, and hegemony. New York: University Press of America.

Kurian, M. 2000. Principles for CPR theory. The Common Property Resource Digest 53: June.

Lacan, J. 1999. The mirror stage as formative of the function I as revealed in psychoanalytic experience. Contemporary In A. Elliot (ed.) Contemporary social theory. Oxford: Blackwell. Pp 61-67.

Lesser, E., Ed. 2001. Knowledge and social capital: foundations and applications. Boston: Butterworth Heinemann.

Leuwis, C. 1993. Towards a Sociological conceptualization of communication in extension science. Sociologica Ruralis XXXIII: 281-305.

Light, A., Ed. 1998. Social ecology after Bookchin. London: Guilford Press.

Meszaros, I. 1989. The power of ideology. London: Harvester Wheatsheaf.

Moeliono, M. 2006. Conservation policy and the commons. The Common Property Resource Digest 76: 1-4.

Moniaga, S. 2000. Advocating for community-based forest management in Indonesia's outer islands: political \& legal constraints and opportunities. IGES International Workshop proceedings.

Munasinghe, S., Ed. 1995. Property rights and the environment: social and ecological issues. Washington D.C.: The World Bank.

Neuman, L. 2003. Social research methods: qualitative and quantitative methods. Boston: Pearson Education.

Nightingale, M. nd. 'Great Wall of Tongke Tongke': climate change \& disaster risk management and so much more. A case study from South Sulawesi. IUCN. http://cmsdata.iucn.org/downloads/great_wall_of_tongke_tongke_2.pdf

Nuijten, M. 2005. Power in practice: a force field approach to natural resource management. Journal of Transdisciplinary Environmental Studies 4(2): 1-14.

Ostrom, E. 1990. Governing the commons: the evolution of institutions for collective actions. Cambridge: Cambridge University Press.

Ostrom, E. 1993. Institutional arrangements and the commons dilemma. In Ostrom V., D. Feeny and H. Picht (Eds.) Rethinking institutional analysis and development: issues, alternatives and choices. San Francisco: ICS Press. Pp101-127.

Ostrom, E. 1994. Neither market nor state: governance of common pool resources in the twenty first century. Washington, D.C.: International Food Policy Research Institute.

Ostrom, E. 1995. Constituting social capital and collective action. In R.E.Keohane and E.Ostrom (eds.) Local commons and global interdependence. London: Sage Publications. Pp 125-161.

Ostrom, E. (Ed.) 2001. Institutions, ecosystems and sustainability. New York: Lewis Publishers.

Ostrom, E. (Ed.) 2007. Understanding knowledge as a commons: from theory to practice. Boston: MIT Press.

Pels, D. 2003. Unhastening science: autonomy and reflexivity in the social theory of knowledge. Liverpool: Liverpool University Press.

Plumwood, V. 2002. Environmental culture: the ecological crisis of reason. London: Routledge.

Prioharyono, E. 2002. Management of mangrove forests: conversion and reforestation of mangrove on the coast of Paojepe, Bonepute and Tongke Tongke, South Sulawesi. Jakarta: University of Indonesia. 
Resosudarmo, B. (Ed.) 2006. The politics and economics of Indonesia's natural resources. Singapore: RFF Press.

Rohdewohld, R. 1995. Public administration in Indonesia. Melbourne: Montech.

Rourke, F. E., (Ed.) 1986. Bureaucratic power in national policy making. Boston: Little Brown and Co.

Satria, A. 2002. Pengantar sosiologi masyarakat pesisir. Jakarta: Cidesindo.

Savitri, M. 2006. Change without reform? Community forestry in decentralizing Indonesia. Bali: IASCP.

Scoones, I. and Thompson, J.T., (Eds.) 1994. Beyond farmer first rural people's knowledge, agricultural research and extension practice. London: Intermediate Technology Publications.

Siswanto, W. 2005. Decentralization of the forestry sector: Indonesia's experience. In Pierce-Colfer C.J (ed.) The politics of decentralization: forests, people and power. London: Earthscan.

Soja, E.W. 1989. Postmodern geographies: the reassertion of space in critical social theory. London: Verso.

Steins, N.A. 1999. All hands on deck - an interactive perspective on complex common-pool resource management based on case studies in the coastal waters of the Isle of Wight (UK), Connemara (Ireland) and the Dutch Wadden Sea. Published Ph.D., Wageningen University.

Thorburn, C. 2001. Regime change. prospects for community based resource management in post new order Indonesia. IASCP Inaugural Pacific Regional Meeting, Brisbane, Australia.

Turnbull, D. 2005. Masons, tricksters \& cartographers: comparative studies in the sociology of scientific \& indigenous knowledge. London: Routledge.

Weick, K. 1995. Sensemaking in organizations. London: Sage Publications.

Wenger, E. 1998. Communities of practice: learning, meaning \& identity. Cambridge: Cambridge University Press.

Yin, R. K. 1984. Case study research: design and methods. London: Sage Publications.

YTMI 2003. Tongke Tongke dalam perspektif pembangunan partisipatif. Makassar: YTMI, UNDP, UNICEF. Zey, M., Ed. 1992. Decision making: alternatives to rational choice models. London: Sage Publications. 


\begin{abstract}
Theorists of Common Pool Resources (CPR) management suggest that distribution and devolution of power can localize consequential decisions over natural resources. The Government of Indonesia has encouraged the collective management of natural resources through self-governed local communes. It has also argued for consensual decision making over the use, allocation and distribution of natural resources at the village, district and regency level. Devolution has not, however, given most people access to strategic and structural power to decide on natural resource governance. Two cases in South Sulawesi are discussed. In the case of the hunting of Sinjai's bats, devolution for collective governance was marked by contention, unfettered competition, and resource overutilization. Management of Sinjai's coastal mangroves, however, suggests that social institutions can stimulate social sensibility, encourage attachment to the natural landscape, and instigate collective responsibilities. Community members acted in a way that benefited the overall good, avowing individual rights. Barriers and enablers to sustainable natural resource governance emerged from the local context in each case, including assertion of private ownership of mangrove plots; they did not emerge as a consequence of distribution and devolution of power alone, as CPR theory suggests.
\end{abstract}

Keywords: Devolution, collective action, reciprocity, ecological sensibility, mangroves, South Sulawesi

\title{
Résumé
}

Les théoriciens de "Common Pool Resources" (CPR) suggèrent que la distribution et la dévolution du pouvoir peut localiser la prise de decisions sur les ressources naturelles. Le gouvernement de l'Indonésie a encouragé la gestion collective des ressources naturelles par les communes locales. Il a également plaidé pour des décisions consensuelles sur l'utilisation, la répartition et la distribution des ressources naturelles au village, de district et au niveau régence. La dévolution n'a pas, toutefois, étant donné la plupart des gens l'accès à pouvoir stratégique et structurel pour prendre leurs propres décisions. Deux études de cas dans le sud de Sulawesi sont discutés. Dans le cas de la chasse des chauves-souris de Sinjai, la dévolution de la gouvernance collective a été marquée par les conflits, et la surexploitation des ressources. La gestion des mangroves côtières, cependant, suggère que les institutions sociales peuvent stimuler la sensibilité sociale, d'encourager l'attachement au paysage naturel, et d'engager les responsabilités collectives. La communautaires ont agi d'une manière qui a bénéficié le groupe, avouant les droits individuels. Les obstacles et les facilitateurs à la gouvernance durable des ressources naturelles a émergé à partir du contexte local dans chaque cas, y compris l'affirmation de la propriété privée des parcelles de mangrove. Ils n'ont pas émergé comme une conséquence de la distribution et la dévolution de pouvoir à lui seul, que suggère la théorie CPR.

Mots-clés: la dévolution, l'action collective, réciprocité, la sensibilité écologique, les mangroves, SulawesiSud

\section{Resumen}

Los teóricos de la gestión de "recursos de acervo común" [Common Pool Resource, CPR)] sugieren que la distribución y devolución de poder puede localizar decisiones trascendentales acerca de recursos naturales. El gobierno de Indonesia ha alentado la gestión colectiva de recursos naturales a través de comunas locales autogobernadas. También ha apoyado las decisiones tomadas por consenso respecto al uso, reparto y distribución de recursos naturales en los niveles de pueblo, distrito y comarca. La devolución, sin embargo, no ha dado a la mayoría de la población acceso a poder estratégico y estructural para decidir sobre la gobernanza de recursos naturales. Se discuten dos casos en Sulawesi. En el caso de la caza de murciélagos Sinjai, la devolución de la gobernanza colectiva quedó marcada por las diferencias, la competencia incontenida y la sobreutilización. La gerencia de los manglares de las costas de Sinjai, no obstante, sugiere que las instituciones sociales pueden estimular la sensibilidad social, fomentar la relación con el medio natural e instigar responsabilidades colectivas. Los miembros de la comunidad actuaron de tal manera que benefició al bien común, respetando los derechos individuales. Los factores que dificultaban y posibilitaban la gobernanza sostenible de recursos naturales emergieron en ambos casos del contexto local, incluyendo la afirmación de la propiedad privada de los lotes de manglares; no emergieron como consecuencia de la distribución y la devolución del poder en sí, como la teoría CPR sugiere.

Palabras clave: devolución, acción colectiva, reciprocidad, sensibilidad ecológica, manglares, Sulawesi del Sur. 